\title{
Terrorism Prevention and the Right of Preemptive Self-Defense
}

\author{
Jaemin Lee*
}

\section{Introduction: Right of Preemptive Self-Defense in the Era of Surging International Terrorism}

The concept of right of self-defense has long been recognized under international law. In general, its legitimacy and necessity have been rarely challenged and almost universally accepted by states. The actual application of the concept to a specific situation, however, almost always has led to fierce confrontation among interested parties regarding whether the international situation at issue indeed warrants exercise of the right of self-defense. This is mainly caused by a fact-specific and case-specific nature of the concept. Therefore, when a "prospective element" is added to this already laden and fiercely debated concept, and thus when the debate is about whether an uncertain future event may authorize the exercise of the right of self-defense, the issue inevitably invites further complication.

Apparently, this seems to be what is going on with respect to the concept of so-called "preemptive self-defense." The preemptive self-defense (or anticipatory self-defense) is generally understood to be an expansion of the traditional right of self-defense. It appears that the issue of preemptive self-defense first appeared in 1967, when Israel initiated military operation against Egypt based on intelligence that its Arab neighbors were allegedly planning to attack Israeli military positions. Israel again resorted to preemptive self-defense in 1981 by raiding and destroying a nuclear power facility in Iraq, also based on the information that Iraq was allegedly engaged in the development of nuclear weapon that could be used against it. Given the fact that the 1981 raid was not triggered by the information of imminent attack as shown in 1967, the aerial raid

* Associate Professor of Law, Hanyang University, Seoul, Korea. LL.B./ Ph.D. (S.N.U.), Juris Doctor (Boston College), LL.M. (Georgetown)). The topic of this paper was presented at the Trilateral Conference held in Konstanz University (among Konstanz University of Germany, Kansai University of Japan and Hanyang University of Korea) in Germany on June 21, 2006. 
fomented more controversy over the issue of preemptive self-defense and its scope.

Similar logic was also adopted by the United States when it was contemplating an invasion of Iraq in 2003.1 On March 20, 2003, the Bush administration initiated a military operation against Iraq by asserting Iraq's alleged possession of Weapons of Mass Destruction ("WMD”) and its future threat to the security of the United States. By going forward with the concept of preemptive self-defense, the Bush administration apparently tried to keep the U.N. Security Council at bay, and resorted to unilateral military operation against Iraq. ${ }^{2}$ Basically, the United States argued that the invasion was critical to protect its people and interest both at home and abroad, before an actual wave of attacks reaches the U.S. borders, which was then known as the "Bush Doctrine." 3 Despite the failure to locate a WMD and waning support for the war, this doctrine (or its equivalent) seems to be still maintained by the United States. 4 In any event, the U.S. action in Iraq and the underlying doctrine in the post-September 11 era have triggered more debates in the international community on the issue of right of preemptive self-defense. In spite of the importance to build and maintain international consensus on this issue, unfortunately there does not seem to be a reliable guideline for states on this issue. 5

1 Richard Falk, The New Bush Doctrine, The NATion (July 15, 2002). For instance, the Bush administration unveiled a sweeping new national security strategy yesterday, declaring that the United States is prepared to launch preemptive strikes against terrorists and nations that threaten America with weapons of mass destruction. See Tom Bowman, Bush Details Preemptive Strike Policy, Chicago Tribune, Sept. 22, 2002.

2 To circumvent the intervention of the U.N. Security Council, a state needs to refer to the right of self-defense provided in Article 51 of the U.N. Charter. See U.N. Charter art. 51.

3 Rachel S. Taylor, Article 51 and the Argument for the Pre-emptive Self-defense, WorLd Press REviEW, available at http://www.worldpress.org/specials/iraq (last visited on Oct.1, 2008).

4 For instance, despite growing concern and anti-war sentiment within the United States, President Bush on March 16, 2006 reaffirmed his first-strike policy against terrorists and rogue nations. In the National Security Strategy of the United States of America, a report prepared and published by the White House regarding the current status of war against terrorism, President Bush made clear that the policy of preemptive strike is a key element in the U.S.'s right of self-defense. He stated that:

To forestall or prevent such hostile acts by our adversaries, the United States will, if necessary, act preemptively in exercising our inherent right of self-defense. The United States will not resort to force in all cases to preempt emerging threats. Our preference is that nonmilitary actions succeed.

And no country should ever use preemption as a pretext for aggression.

White House, National Security Strategy of the United States of America (March 16, 2006), at 18. See also Bill Nichols and Barbara Slavin, New Security Strategy Reaffirms Bush's Preemptive Strike Policy, USA TODAY (Mar. 16, 2006). In this regard, one commentator states that President Bush was the first U.S President to explicitly support the doctrine of preemptive self-defense as a rationale for going to war. See Matthew Klapper, The Bush Doctrine and North Korea, 8 Gonz. J. INT'L L. (2004-05).

5 Still, it appears that the scholars are sharply divided over the legitimacy of the preemptive self-defense. See, e.g., Mary Ellen O'Connell, The Myth of Preemptive Self-Defense, paper published by the American Society of International Law Task Force on Terrorism 2-3 (Aug. 2002). 
Worse yet, the issue of preemptive self-defense is getting more complex as it stands currently; the preemptive self-defense is now being discussed in the context of terrorism prevention, which invites another layer of volatility and political sensitivity among various countries. It is imperative that the international community should come up with a cooperation network to cope with the surging international terrorism, and that individual states' right to protect themselves from terrorism should be permitted within the ambit of international law. Due to the unique characteristics of threats posed by terrorism and the lack of legal coherence in defining and identifying terrorism, however, preemptive self-defense in the context of terrorism prevention apparently implicates more elements to consider and probably requires a different approach. It is well known that various international organizations, including the United Nations, have been mobilizing collective efforts to deal with the surge of international terrorism. 6 Nonetheless, it is also incumbent upon the international jurists to contemplate relevant legal issues arising from preemptive self-defense, coupled with its unique characteristics, in the course of terrorism prevention.

Furthermore, this issue is not merely confined to U.S. global counter-terrorism effort or Middle East policy. Given that terrorism also stands ready to be spread in some regions of Asia and that preemptive self-defense has been indeed mentioned in the context of recent conflicts in the region, 7 this issue could be easily raised in the backyard of Asia as well.

In a sense, the concept of right of preemptive self-defense in the context of international terrorism is bound to be complex; as both preemptive self-defense and international terrorism are loaded with volatility and political sensitivity on their own, it becomes further complicated when the two are combined. With these issues in mind, this paper attempts to briefly examine relevant issues of preemptive self-defense in the context of terrorism prevention and to offer a guideline in approaching this issue.

\section{The Framework under the U.N. Charter}

International law has divided situations surrounding a war into three categories: jus ad bellum (addressing the right to use force), jus in bello (addressing how to use force during a conflict), and jus post bellum (addressing cessation and postludes to war). 8

6 For example, following the increased Security Council management of the United Nations' anti-terrorism strategy after September 11, the General Assembly continued to adopt resolutions calling on states to eliminate international terrorism. See U.N. Doc. A/RES/56/88, at para.16 (Jan. 24, 2002).

7 Daniel A. Pinkston \& Kazutaka Sakurai, Japan Debates Preparing for Future Preemptive Strikes against North Korea, 18 Korean JouRnal of DefEnse ANALysis 96, 110-112 (Winter 2006).

8 See Notes, War, Schemas, and Legislation: Analyzing the National Discourse About War, 119 HARV. L. REv., 2099, 2105 (2005). 
Among these, self-defense is related to the first category, where the core issue is whether a war at issue is legitimate or just. With the danger of over-simplification, an argument could be made that a state's military operation adopted only for the purpose of coping with terrorist attacks and confined only to the boundary to protect its people and property may fall under one of the situations of a legitimate or just war. ${ }^{9}$ If that is the case, one could further argue that a state or an entity that supports or sponsors such terrorist attacks could become a legitimate target of self-defense to the extent the exercise of the right is limited to the specific threat thus identified. The general characterization as such may be able to get consensus easily, but the actual application of the concept in a particular context is far from simple.

\section{Right of Self-Defense under Customary International Law}

The right of self-defense has long been recognized under customary international law. 10 As is well known, the Caroline case provides a classic guideline for the right of selfdefense under customary international law. This case arose from a dispute between the United States and Great Britain over an 1837 incident, where British forces, claiming self-defense, seized an American steamboat transporting supplies to a Canadian rebel group, and destroyed it. The self-defense jurisprudence established from this case is to the effect that exercise of self-defense is limited to instances in which the "necessity of self-defense is instant, overwhelming, and leaving no choice of means, and no moment for deliberation."11 In other words, any use of force in self-defense must respect the principles of necessity and proportionality; necessity restricts the use of military force to the attainment of legitimate military objectives, 12 and the proportionality requires the countermeasure adopted to be proportional to the threat posed.

This jurisprudence has been widely accepted as a guideline in examining a dispute over self-defense. One could thus argue that that the Caroline formula has established itself as customary international law. The Caroline formula is also believed to have been reflected in the letter and spirit of the U.N. Charter, where the right of self-defense is explicitly provided for the member states. 13 Thus, it appears that any discussion on the issue of self-defense should be based on the Caroline formula.

10 S.C. Res. 1368; UN Doc. SC/7143; S.C. Res. 1373; UN Doc. SC/7158.

11 R. Y. Jennings, The Caroline and McLeod Cases, 32 Am J. InTL. L. (1938); Oscar Schachter, InTERNATIONAL Law in Theory and Practice 150-52 (Kluwer 2d ed. 1991).

12 Advisory Opinion on the Legality of the Threat or Use of Nuclear Weapons, 1996 I.C.J. 226, at para. 41.

13 Mary Ellen O'Connell, supra note 5, at 9. 


\section{U.N. Charter}

The U.N. Charter imposes a strict rule against the use of force by member states. As the International Court of Justice ("ICJ") in Nicaragua v. United States articulated, the U.N. Charter is based on the fundamental principle outlawing the use of force in international relations except in rare circumstances. 14 As such, Articles 2(4) and 51 of the U.N. Charter were introduced to prohibit the use of military force except when necessary to repel an "armed attack." Although the use of military force with the authorization of the Security Council under Chapter VII of the U.N. Charter also constitutes an exception, as far as a state's unilateral decision and action for military operations is concerned, Articles 2(4) and 51 are the two relevant provisions in the U.N. Charter. To begin with, Article 2(4), as one of the principles of the U.N. Charter, provides that:

All Members shall refrain in their international relations from the threat or use of force against the territorial integrity or political independence of any state, or in any other manner inconsistent with the Purposes of the United Nations. (emphasis added)

Although Article 2(4) does not contain an exception in the provision itself, a critical one is provided in Article 51 of the U.N. Charter, which provides that:

Nothing in the present Charter shall impair the inherent right of individual or collective self-defense if an armed attack occurs against a Member of the United Nations, until the Security Council has taken measures necessary to maintain international peace and security. Measures taken by Members in the exercise of the right of self-defense shall be immediately reported to the Security Council and shall not in any way affect the authority and responsibility of the Security Council under the present Charter to take at any time such action as it deems necessary to maintain or restore international peace and security. (emphasis added)

So, Article 51 basically reaffirms that if a state is attacked, it may use force to defend itself, as it could do under customary international law. Through the wording of "inherent right," the provision also makes clear that this right is not something newly created by the U.N. Charter, but that the Charter simply recognizes an already existing right of individual states. Here again, one could confirm that the relevant customary international law principles developed from the Caroline case still plays an important role in disputes about the right of self-defense. In any event, Article 51 is the key provision that should be referred to whenever there is a dispute over the legitimacy of exercising the right of self-defense among U.S. member states, which basically includes 
almost all states in the international community.

As it currently stands, although this provision does stipulate procedural hurdles in the course of exercising self-defense, it does not offer a specific guideline to determine in what situation the right of self-defense could be legitimately exercised. Examination and determination on legitimacy or legality in specific instances are reserved for discretion of respective individual states, as the holder of "inherent rights." Of course, any decision by an individual state may be subject to the review of the ICJ to the extent its jurisdiction is properly established in a particular case. But the initial decision for the exercise of the right of self-defense is first made by an individual state concerned regardless of whether the decision is indeed found consistent with Article 51 or not: action occurs first and review only comes afterwards even if there is one. Such being the case, this issue is by nature prone to a dispute among interested parties. Given the enormity of interest and danger at stake, any dispute in this area may well develop into a severe international conflict.

Indeed, there is a wording in the Article that has specific relevance to the preemptive self-defense. The Article permits exercise of the right of self-defense "if an armed attack occurs." This language, when literally read, apparently restricts preemptive selfdefense, because it seems to allow self-defense only if an armed attack actually occurs. The drafters could have easily provided that "if an armed attack occurs or is likely to occur," or inserted any similar language to that effect. So, one could refer to this language as a ground that the U.N. Charter does not allow preemptive self-defense. General rules of treaty interpretation as set forth in 1969 Vienna Convention on the Law of Treaties dictate that treaty interpretation begins with an "ordinary meaning" to the treaty terms used.15 On its face, the language in Article 51 apparently limits the right of self-defense to the actual occurrence of initial armed attack by an aggressor. One could thus argue that the ordinary meaning of the Article imposes interpretation that the U.N. Charter basically disproves the preemptive self-defense.

This view also seems to be supported by the ICJ in the Nicaragua case, where it determined that the right of individual or collective self-defense is triggered only by acts tantamount to an armed attack.16 Relying in part on the UN General Assembly's definition of aggression, the ICJ in that case concluded that an "armed attack" triggering unilateral self-defense may include "the sending by or on behalf of a State of armed bands, groups, irregulars or mercenaries, which carry out acts of armed force against

15 Article 31 (1) of the 1969 Vienna Convention on the Law of Treaties provides as follows: General rule of interpretation

A treaty shall be interpreted in good faith in accordance with the ordinary meaning to be given to

the terms of the treaty in their context and in the light of its object and purpose. (emphasis added)

16 See Nicaragua case, at paras. 194-95, 211. 
another State of such gravity as to amount to ... an actual armed attack conducted by regular forces...."17 Therefore, from this language, one could argue that both the ordinary meaning of the words "if an armed attack occurs" and the jurisprudence of the ICJ basically negates the concept of the right of preemptive self-defense, or at least allows it in a situation where the circumstances are almost same as or equal to an actual occurrence.

It seems questionable, however, whether this view is indeed accurate at all times. First of all, provisions in the U.N. Charter should be interpreted in a way that achieves the basic principles of the U.N. and the underlying spirit of the provisions at issue. Both the principles of the U.N. as provided in Article 2 and the spirit of Article 51 apparently make clear that "although aggressive war is now generally prohibited, states still may resort to the right of self-defense in certain situations." Once this basic theme is confirmed, it would not be necessarily appropriate to attach too much meaning to the existence or absence of a particular word in a way that might undermine the basic theme. It should also be noted that the U.N. Charter only provides a framework for the legal norms for the states rather than detailed step-by-step instruction for all imaginable situations. If the Charter is indeed designed to be a detailed instruction, as is usually seen in trade agreements, then we would have to be bound by the provisions "to the letter." But this does not seem to be the case and sometimes the U.N. must fill the holes of the Charter, adequately reflecting the ever-changing nature of the international community.18 Likewise, the concept of the right of self-defense should not be insulated from the changing reality of modern warfare, where a first strike, if unchecked, could be a decisive factor for the outcome.19 In short, a counter-argument could be made in favor of preemptive self-defense by stressing that; (i) the "context" of the provision generally recognizing the right of self-defense should also apply to other variations of self-defense including a preemptive one, commensurate with the changing environment of modern warfare and that (ii) the "object and purpose" of the U.N. Charter 20 are not to disregard the sovereignty of member states to preserve its territorial integrity and legitimate interests through the right of self-defense including a preemptive one, unless specifically delegated to the U.N.21

Secondly, it is also doubtful whether the language of the Nicaragua case generally negates the concept of preemptive self-defense. The holding of the ICJ in that case does

17 Id. at paras. 194-95.

18 See Certain Expenses Case, at para. 220.

19 Brunno Simma (ed.), The Charter of the United Nations: A Commentary 51 (Oxford 1994).

20 Robert Hill, Preemption: The U.N. Charter Is Outdated, InTERnATIONAL Herald Tribune, Dec. 2, 2002.

21 For instance, While Articles 1 and 2 of the U.N. Charter provide purposes and principles of the U.N., they do not include a reference to the effect that U.N. Charter restricts individual state's inherent right unless and until explicitly provided in the Charter. 
not necessarily restrict exercise of the right of self-defense to occurrence of an actual armed attack. Rather, the Court refers to a situation where acts of armed forces are grave enough to amount to an armed attack.22 "Amounting to" something basically connotes that the something has not actually happened yet: that is, something has not happened yet, but the situation is almost the same as or comparable to the something. So, the holding of the case could be more properly understood as stipulating that preemptive self-defense should be cautiously interpreted as opposed to rejecting the concept categorically.

All in all, therefore, it seems more plausible that preemptive self-defense could be recognized under the current U.N. Charter as long as the prerequisite conditions for the right of self-defense under the customary international law including the guidelines mentioned in the Caroline case are sufficiently met. ${ }^{23}$ For instance, as one scholar puts it, preemptive self-defense could be exercised "where there is convincing evidence not merely of threats and potential danger but of an attack (or preparation for an attack) being actually initiated, though it has not passed the frontier.24 So, under this standard, an enemy fleet moving toward the key ports with an apparent intention of initiating hostile engagement may provide the ground for preemptive self-defense while mere possession of weapons of mass destruction or having a future plan for an attack, without more, may not. 25

Of course, in the context of preemptive self-defense, the exercising state would face more difficult task of fulfilling its burden of proof than an ordinary self-defense situation, because the evidence and materials in preemptive context are only prospective in nature. 26 However, as long as the exercising state successfully fulfills its burden of proof based on the Caroline standard, there does not seem to be a particular ground to categorically dismiss preemptive self-defense as illegal under international law.

22 Nicaragua case, at paras. 194-95.

23 Professor Bruce Ackerman of Yale Law School also argues that there is a limit in exercising the right of preemptive self-defense, that the U.S. government has traditionally recognized this limit, and that invasion of Iraq, however, seems to fall outside the traditional limit. Bruce Ackerman, But What's the Legal Case for Preemption?, Washington Post, Aug. 18, 2002.

24 C.H.M. Waldock, The Regulation of the Use of Force by Individual States in International Law, 81 HAGUE RECUEL 451, 498 (1956).

25 See e.g. Mary Ellen O'Connell, supra note 5, at 9, 11.

26 One scholar mentioned that there are three ways that a state can abuse the right of preemptive self-defense. First, the alleged attack may never have materialized. Second, under a broad construction of self-defense, states may invent anticipated attacks as a pretext. Third, the attacking state may be mistaken as to the other nation's intent. Dawn M. Gibson, A Virtual Pandora's Box: Anticipatory Self-Defense in Cyberspace (2004), available at http://www.uiowa.edu/ cyberlaw/csl03/dgcsl03.html (last visited on Oct 10, 2008). 


\section{Problems under the Current Regime Concerning Terrorism Prevention and Preemptive Self-Defense}

Again, the actual application of these concepts to the real situation is confusing and complex. When does the right of self-defense legitimately start under international law? Does that limit self-defense to a situation where an enemy attack crosses a border or otherwise actually begins?27 If one country can take a preemptive measure when an attack is imminent, how imminent should it be? It is never easy to answer these questions. Also, the answers to these questions may vary from situation to situation, given the fact-specific nature of the self-defense inquiry under international law. ${ }^{28}$ In any event, however, any rule that requires a country to wait for the first blow from another country before it legitimately exercises the right of self-defense does not appear to function properly in the modern world filled with potent weaponry. So, in short, the concept of preemptive self-defense could be basically accepted as legitimate by the international community. Whether the exercise of preemptive self-defense in a particular context is justified, however, is a totally different question, which would require an in-depth inquiry into all the relevant circumstances of the case at issue to determine if elements of self-defense have been duly satisfied. As such, if international

27 IAn Brownle, International LaW AND the Use of Force by States 275-80 (Oxford 1963).

28 For instance, even if there is consensus that preemptive self-defense is permitted under international law, there are still sharp debates going on whether a particular situation indeed meet the threshold. William Bradford, Assistant Professor of Law, Indiana University School of Law, is of the view that the Iraqi invasion is justified as preemptive self-defense. He stated that:

There should be scant surprise that in practice presidents have acknowledged and embraced the 'great object and duty' with which natural law charged them to defend U.S. lives, liberty, and property through 'prompt and decided action.' Viewed in this light, the Bush Doctrine, notwithstanding its proclamation of the unilateral right to engage in preventive war, is revealed as nothing more than a renewed commitment to the natural law duty to defend which is at once wholly consistent with the letter and spirit of international law as well as with the object and purpose of the Framers of the U.S. Constitution.

William, Bradford, The Duty To Defend Them: A Natural Law Justification for the Bush Doctrine of Preventive War, 79 Notre Dame L. Rev. (2004). On the other hand, Duncan E. J. Currie, former legal counsel to Greenpeace, argues that the invasion cannot be justified under preemptive self-defense. He stated that:

"The guarantees of international peace and security and the determination to avoid the scourge of war put in place following World War II have been undermined and even imperiled by the use of military force under the doctrine of 'preventive war' and the invasion of Iraq. It is critical that member States following the attack on Iraq re-acknowledge their commitment to avoiding war and to the principles and purposes of the United Nations Charter, in order that the role of the rule of law in avoiding future wars may prevail."

See Duncna, E.J. Currie, Preventive War and International Law After Iraq: go to the Greenpeace website, available at http://wwwgreenpeace.org/international/press/reports/preventive-war-and-internet (May 22, 2003) at 21 (last visited on Oct. 1, 2008). 
terrorist groups are planning a series of attacks against a state in a terrorism campaign, the state may be permitted, depending upon the quantity and quality of the threat, to respond militarily in order to prevent future attacks. The exercising state, however, must present specific evidence that sufficiently meets the customary international law including the Caroline standard and/or requirements under Article 51 of the U.N. Charter.

Even if we accept that the concept of preemptive self-defense needs to be recognized as legitimate expansion of the inherent right of self-defense, the application of the concept to the terrorism prevention at issue here requires more careful consideration. That is because the underlying problems and uncertainties surrounding preemptive self-defense are further exacerbated in the terrorism prevention context due to the unique characteristics of international terrorism. Unique characteristics regarding preemptive self-defense in the context of international terrorism could be briefly summarized as follows.

\section{Involvement of Non-State Actors}

The rules of self-defense under the current U.N. Charter regime and customary international law have been developed with nation-states in mind, a situation where one country is attacked by another country. However, as the term "inherent" in Article 51 of the U.N. Charter connotes, there does not seem to be any compelling reason for self-defense to be necessarily confined to the situation where the exercising state is being attacked by another state only. The right should be equally recognized vis-à-vis attacks from non-state actors, if any, provided that such attacks, in various respects, constitute similar threats to the exercising state as contemplated in Article 51 of the U.N. Charter. After all, if the right is something inherent, there is no reason for us to distinguish the sources of the threat. Otherwise, the notion of self-defense would become an empty shell, given the increasing role played by non-state entities in the current international community.

The September 11, 2001 attacks against the United States may provide a vivid example. The incident demonstrated that nowadays non-state actors have emerged, and that they are able to wage an armed conflict with a power that only nation-states once possessed.29 As a matter of fact, given their strong determination and military hardware within their possession, these actors are, to some extent, even stronger than some conventional nation-states. Thus, there seems to be actually growing necessity to 
recognize the right of self-defense in this kind of situation. 30

The emergence and involvement of non-state actors, however, make the right of selfdefense in the context of terrorism prevention more complicated. First of all, since nonstate terrorist groups are not confined to a traditional boundary of a state, it is sometimes murky as to which state or whose territory should be the target of the counter-measure arising from the right of self-defense, even if all elements of selfdefense have been somehow met. Should the country where the mastermind resides be the target, should the country where the majority of military force is located be the target, or should any country that has relationship with the terrorist group become a fair game? It is not entirely clear. Furthermore, the concept of preemptive strike adds another layer of complexity here. For instance, in this case, can the exercising state resort to a military force against a state which is simply expected to offer an operating place for the non-state actors? In addition, what about a state which is not aware of terrorists' current operation or a future plan of operation within its territory? Should it accept the exercising state's exercise of right of self-defense? Preemptive self-defense against terrorists brings all these complex questions.

The concept of preemptive self-defense itself is a fact-specific, complicated issue, as noted above. But the preemptive self-defense in the terrorism prevention context is all the more complex because of this amorphous nature of terrorist activities not confined to traditional boundaries of states, which are carried out by non-state actors. It would subject the already fluctuating concept of preemptive self-defense to more uncertain and arbitrary decisions by interested parties, which would lead to more fierce legal controversy in the days ahead.

30 For instance, with respect to Iraqi invasion Anne-Marie Slaughter, Dean of the Woodrow Wilson School of Public and International Affairs, Princeton University, mentions that the terrorism attack is different from the conventional warfare and indicates broader application of preemptive self-defense may be justified. She stated that:

\footnotetext{
The reason you now need to talk about preventive war rather than preemptive war is because we are facing the kinds of threats where you're not going to be able to know when the threat is imminent. Preemptive war, the classic example is the Israeli war in 1967. The armies are amassing on the borders. You know they're about to strike and you strike first. That's preemptive war. That's--the threat is imminent.... Now the question is precisely that -- take what happened 9/11 or take you think that some country is about to get nuclear weapons and they are funding terrorists and they are -- so imagine the Taliban was about to go nuclear. Well at that point, you know that if you wait till the threat is imminent, it's too late. By then, you're not going to -- if they've got a nuclear weapon, you're not going to wait around wondering when they're going to use it. So you have to strike beforehand."
}

Anne-Marie Salughter's Statement during "Uncommon knowledge with Peter Robinson," an interview program by the Hoover Insititution in Stanford University concerning preemption titled "The Best Defense: Preemptive War," (May 26, 2005), available at http://www.hoover.org/multimedia/uk/2939386.html. 
Furthermore, the increasing involvement of non-state actors in armed conflict is not simply confined to the terrorist groups. The same is also true with the party that purports to exercise the right of self-defense against the terrorist groups. Thus, one observer opined that:

\begin{abstract}
Although many Americans still visualize the U.S. military as a monolithic force of uniformed personnel only, the reality is far different. Due to federally imposed personnel limitations for the armed forces and the need for specialized skills in the modern high-tech military, hundreds of activities once performed by the military are now privatized and outsourced to thousands of civilian contractors. 31
\end{abstract}

The increasing tendency of "privatization" and "outsourcing" on the part of the state allegedly exercising the right of self-defense adds another twist to the situation. The entities that exercise the right of self-defense are sometimes not conventional armed forces, but "contractors" from private companies or from other countries. In short, sometimes it becomes non-state actors versus non-state actors in an alleged self-defense conflict. When non-state actors are utilized in the exercise of preemptive self-defense, the degree of intrusiveness on the part of the country that has become the target of preemptive strike due to the presence of terrorist operation would be higher than it otherwise would be. That would be particularly the case if non-state actors from both sides are engaged in military conflicts within the territory of the country which is not necessarily responsible for the terrorist activity in its territory.

Therefore, the situation would be even murkier when preemptive self-defense is applied in the context of terrorism prevention, because it is basically an exercise of the right of self-defense against a non-state entity without a clear border or sphere. The terrorists belonging to a particular group could be ubiquitous, but it would not be easy to single out a state or a place within a state as a target of self-defense.

\title{
Minimum Threshold Requirement
}

In addition, one thing to note in this respect seems to be that an attack initiated or feared to be initiated by non-state actors should meet a certain minimum threshold, both in terms of quantity and quality of the aggression or threat of aggression thus posed. This threshold is about the quantity and quality of the attack and attackers themselves, so it is rather different from the Caroline standard, which mainly focuses on the perception on the side of the state being attacked. For instance, a terrorist attack that gives rise to

31 Jeffrey F. Addicott, Contractors on the "Battlefield:" Providing Adequate Protection, Anti-Terrorism Training and Personnel Recovery for Civilian Contractors Accompanying the Military in Combat and Contingency Operations, 28 Hous. J. INT'L L. 323, 325 (2006). 
the exercise of the right of self-defense should be something systematic and organized, which is being planned and orchestrated by a leader or mastermind and which is being directed to another state or a group of states where the exercising state belongs. It would be impossible to come up with exact quantification for this threshold, but it is necessary to recognize that there has got to be some dividing line between the two situations of international terrorism; a situation which belongs to law enforcement authority of a state, and a situation which triggers the issue of self-defense under international law due to the intensity and enormity of the terrorist attack.

Without this notion of minimum threshold, any terrorist activity with sizable enormity could arguably offer a ground for the exercise of right of self-defense, whether preemptive or present. This, however, does not seem to lead to a reasonable conclusion: although it certainly is true that a terrorist activity may certainly constitute a crime to be punished, either under domestic law or international law as the case may be, that does not necessarily provide a sufficient ground for exercising the right of self-defense under international law. In other words, with regard to international terrorism, domestic or international criminal proceedings and the issue of self-defense should be distinguished from each other. A situation which warrants a necessary law enforcement response does not guarantee that it also permits exercise of self-defense as authorized under international law.

Article 51 of the U.N. Charter could also be reviewed from this perspective. As noted above, as a precondition for the exercise of right of self-defense, Article 51 imposes a requirement that "if an armed attack occurs." The word "armed attack" here should be understood to mean a systematic attack against another country planned and orchestrated by a leader, thereby excluding sporadic incidents of international terrorism. Thus, one could argue that Article 51 also generally supports for the proposition that an inquiry into the minimum threshold needs to be conducted when one addresses the issue of self-defense against international terrorists.

Preemptive self-defense against international terrorism, however, seems more likely to blur the dividing line between the law enforcement aspect and the self-defense aspect. The speculative nature of preemptive self-defense against terrorism tends to mix up the results of the investigation into a terrorist activity and a resulting state-wide response to the terrorist activity thus identified. The inevitable outcome is that a military action, even if framed as preemptive self-defense, is actually contemplated as retaliation as a result of the criminal investigation. Thus, with regard to preemptive selfdefense in terrorism prevention context, a more thorough inquiry into the minimum threshold needs to be conducted by the exercising state or a reviewing entity. 


\section{Transnational Nature}

Furthermore, these non-state actors do not operate within the boundary of one state. Instead, most of the time, the current terrorist groups pursue their activities on a global basis. As shown in the Al-Qaeda example, these new terrorist groups are scattered in multiple countries and operate across borders. It is sometimes meaningless to stage an armed attack, in the course of a preemptive self-defense, against one state since the terrorists in the state can be easily relocated to another country. If so, a preemptive strike could simply result in a failed attempt, if the terrorists are easily transferred to a third country, or a chain reaction of strikes against multiple states, if the exercising states continue to exercise the right of self-defense tracking down the terrorists' trail. The latter situation would further undermine the stability of the international community by ruining the relationship among the related states.

Such being the case, it is incumbent that collective efforts are made in addressing the threats from the international terrorists. A unilateral action, be it law enforcement action or self-defense one, would be rarely effective as far as the international terrorism is concerned. An inquiry into a preemptive strike in the context of international terrorism would render meaningless if it only focuses on the right of self-defense of an individual state. A more appropriate inquiry would be whether such individual selfdefense exercise is effective in addressing the problem posed. If it is clear that the exercise of preemptive self-defense will not be effective in dealing with the claimed problem, then it is more likely that such preemptive self-defense would be found illegitimate. It should be noted that individual exercise of preemptive self-defense against international terrorist groups would turn out to be a stop-gap measure, and that an effective preemption could only be achieved through mobilization of collective efforts.

\section{Absence of Definition}

More fundamentally, the international society has yet to come up with a legal definition for "terrorism." 32 There does not exist a reliable definition for terrorism under

32 Ninian Stephen, Toward a Denifition of Terrorism, in C.A.J. CoAdy \& Michael P. O'KeEfE (eds.), Terrorism and Justice: Moral Argument in a Threatened World 1 (2002). In fact, The General Assembly's most significant resolution to date, the Declaration on Measures to Eliminate International Terrorism of 1994 (Elimination Declaration), states that:

2 Acts, methods and practices of terrorism constitute a grave violation of the purposes and principles of the United Nations, which may pose a threat to international peace and security, jeopardize friendly relations among States, hinder international cooperation and aim at the destruction of human rights, fundamental freedoms and the democratic bases of society; See G.A. Res. 49/60; U.N. Doc. A/RES/49/60 (Dec. 9, 1994). 
international law yet. For example, some states, such as Russia or China, think that every act of violence carried out by irregular fighters against the state must be called "terrorism." Other states, on the other hand, consider every act of violence against civilians or non-combatants a terrorist act, even if it is carried out by a state or by an official institution. 33

Under these circumstances, the issue of preemptive self-defense in the context of terrorism prevention inevitably becomes complex; both of the key terms here, that is, "terrorism" and "preemptive self-defense," lack clear definition. As such, the combination of both would certainly lead to wide difference in opinions and positions of various states. It is almost inevitable, therefore, that an international dispute arises when preemptive self-defense is initiated in response to international terrorism.

\section{Suggestion for Future Reform}

To address these problems, following recommendations could be considered in addressing the issue of preemptive self-defense and terrorism prevention. This is not to negate or modify the Caroline standard, but to further fine-tune the preemptive selfdefense in the context of terrorism prevention. As an overview, any new rule to be adopted in this field needs to be tailored as precisely as possible to achieve the purpose; which is balancing the necessity for a state to resort to the use of force to maintain its territorial integrity and the danger flowing from possibilities for disguised uses of force.34 In other words, any new rule to be adopted here should be neither underinclusive nor over-inclusive.

\section{Distinguishing Criminal Procedures and Right of Self-Defense}

First of all, the issue of preemptive self-defense in the context of terrorism prevention should be distinguished from the issue of addressing increasing international terrorism from the law enforcement perspective. Although they are certainly related, they should not be mingled together. It goes without saying that the surge of international terrorism in various places requires effective counter-measures by relevant states. It is also true that without such measures the international community would be put in jeopardy. This line of argument, however, is more directly related to the law enforcement perspective of terrorism prevention as opposed to preemptive self-defense. Rather, preemptive self-defense should be able to be justified on its own accord in accordance with elements required for the legitimate exercise of self-defense under international law.

33 Cyrille Begorre-Bret, The Definition of Terrorism and the Challenge of Relativism (from Symposium on Terrorism, Globalization and the Rule of Law), 27 CARDOZo L. REv.1987, 1989 (2006).

34 Yoo, supra note 29, at 641, 659. 
Future discussion on preemptive self-defense with respect to terrorism prevention, therefore, should be conducted with this distinction in mind. Any attempt to justify, or loosen the rule on, preemptive self-defense based only on the necessity to cope with the surge of terrorism, therefore, must fail. This rationale may provide sufficient grounds for why individual or collective law enforcement efforts are in order for the purpose of suppressing international terrorism, but they hardly provide a sufficient legal basis for the right of preemptive self-defense. Efforts to distinguish preemptive self-defense from criminal investigation could help the international community develop more workable standards in this area.

\section{Consideration of Mitigating Factors}

In evaluating the legitimacy of preemptive self-defense in a specific instance, it is necessary to take into consideration any mitigating factors, if any. This is so, because preemptive self-defense is prospective in nature, and because it is more prone to reasonable interpretation of the situation at hand by the exercising state. For instance, in examining the legitimacy of preemptive self-defense against international terrorism, one of the elements to be considered would be whether the state within which the terrorists operate is somehow responsible for their activity. If the state directly supports the terrorist activity, it would be an easy question. But, if the state is unable or unwilling to cope with the terrorists within its boundary, then the situation is a little murkier. In any event, at least such inability or unwillingness on the part of the terrorist-hiding state could be considered as a mitigating factor in determining legitimacy of preemptive selfdefense against terrorism.

As a matter of fact, the UN International Law Commission has acknowledged the important role of such mitigating circumstances within its influential 2001 Articles on State Responsibility. For instance, when determining whether reparation for a wrongful act is required, the Articles suggest that account shall be taken of any contributory willful or negligent action or omission on the part of the injured party. 35 Although the specific context between state responsibility and the legitimacy of self-defense is different, this shows that the concept of consideration of mitigating factors could be similarly applied.

Similarly, the fact that there appeared to exist sufficient time to seek a prior review by the U.N. Security Council is also an important factor to be considered in determining the legitimacy of any preemptive self-defense. Article 51 implies that the right of self-

35 See Draft articles on Responsibility of States for Internationally Wrongful Acts, Report of the International Law Commission on the Work of its fifty-third Session, Article 39, available at http://www.un.org/law/ilc/texts/State_responsibility/responsibility_articles(e).pdf (last visited on Oct. 4, 2008). 
defense exists only when there is no time to take the issue before the Security Council. ${ }^{36}$ This general rule should equally apply to preemptive self-defense. If there is time for deliberation by the Security Council, such situation would militate against justifiable self-defense. For instance, regarding the U.S. military operation in Iraq in 2003, the threat posed by Iraq, even if true, may have had sufficient time for a deliberation by the Security Council. The fact that the United States attempted to circumvent a deliberation by the Security Council would operate as a factor that goes against the U.S. claim of preemptive self-defense.

Therefore, any discussion on rules of preemptive self-defense against international terrorism should contemplate on how to identify and consider mitigating factors. Involvement of or discussion with international organizations could carry significant weight in this process. This is particularly important in the terrorism context because the surrounding situation is more subtle and confusing than other incidents. Properly considered mitigating factors would reduce the likelihood of disputes over legitimacy of any preemptive self-defense.

\section{Evidence Collection and Evaluation by the U.N.}

In addition, in the United Nations system, the Security Council plays an important role in making a determination that an emergency situation exists and thus exercise of selfdefense is justified. The Security Council is authorized by Articles 25 and 48 of the U.N. Charter to adopt resolutions that bind U.N. member states. 37 International terrorism is almost certainly within the Security Council's province. As a matter of fact, the Security Council proclaimed it one of the "most serious threats to peace and security," thereby making it clear that it can invoke its powers under Chapter VII of the Charter to address issues arising from international terrorism.

Needless to say, preemptive self-defense against international terrorism needs to be subject to a careful scrutiny of an international organization with proper authority. This is particularly the case given the fact that frequently international terrorism implicates multiple countries at the same time. Unless adequately reviewed and coordinated by a reliable international entity, unilateral exercise of preemptive self-defense can plant a seed for a continuing dispute among states. For instance, when Israeli fighters bombed the Iraqi Osirik nuclear reactor in 1981, the Security Council unanimously condemned the bombing regardless of the fact that the Iraqi nuclear weapons could threaten the Israeli security interest. The Security Council thus determined that "the military attack

\footnotetext{
36 U.N. Charter art. 51.

37 U.N. Charter arts. 25, 48.
} 
by Israel is clear violation of the Charter of the United Nations and the norms of international conduct."38 Such evaluation of the U.N., even if post hoc, is still important because it could ensure that other countries understand that such military action is not justified by preemptive self-defense. It would operate as a deterrent for another state considering similar action in the future.

Unlike conventional situations of self-defense, where one state is being attacked by another state and thus where an immediate response in the form of self-defense is a necessity, the situation caused by international terrorism rarely mounts to a situation that requires immediate exercise of the right of self-defense (although it may require immediate law enforcement response). Of course, any prospective terrorist activity does require an immediate response from the prospective victim state, but most of the time the initial response would be provided in the form of law enforcement procedures to prevent or punish particular terrorist activities. Theoretically, there may be instances where the state itself is under a massive attack by an organized entity; in those instances, a state may well resort to its inherent right to protect itself. But such instance would be indeed rare. In the context of terrorism prevention, therefore, most of the time there may be, at least, some time to evaluate the situation. So, the terrorism-based preemptive self-defense should be considered to be subject to more in-depth prior inquiry by an objective entity than other instances of preemptive self-defense.

Even if a terrorist attack with the intensity and magnitude that are usually seen in a state-to-state conflict is expected, where an immediate exercise of preemptive selfdefense is thus arguably permitted, an international entity needs to conduct an ex post facto review to determine the legitimacy of any claimed preemptive self-defense. The absence of consensus on and continuing controversy over the concept of terrorism and preemptive self-defense certainly militates in favor of such an ex post facto review.

Obviously, at this point, the most appropriate evaluating entity in this context would be the Security Council, as the entity that assumes primary responsibility for the maintenance of international peace and security. 39 However, the Security Council's frequently perceived lack of interest or inability to get involved in issues that threatens or constitutes breach of international peace has caused many observers to question the role of the Security Council as contemplated in the U.N. Charter. Under these circumstances, a strict interpretation of Article 2(4) and Article 51 would be indeed detrimental to the inherent right of states to protect themselves.

This situation needs to be remedied as soon as possible, not only for the maintenance 
of world security in general, but also to cope with preemptive self-defense against international terrorism in particular. Unless and until the Security Council, or its equivalent, is in full charge of evaluating a particular situation at issue, international disputes surrounding this issue will continue to increase.

\section{International Cooperation Network}

Given the fact that terrorism prevention mostly involves criminal investigation and law enforcement issue both under domestic law and international law, it is critical for the international community to enhance international networking to deal with these terrorist activities. Extradition treaties and mutual legal assistance treaties would be good examples. Individual efforts by an individual state would only provide a temporary relief to the problem given the ubiquitous nature of international terrorism. The controversial and lukewarm results of the U.S.-led efforts in Afghanistan and Iraq prove the limit of unilateral action to address problems of international terrorism.

Therefore, future discussion on preemptive self-defense should be conducted in a way that fosters international cooperation further. It is true that the concept of selfdefense by nature connotes individual response before a multilateral security system is set to work. However, the international community may exert efforts to make the states aware that establishing an international cooperation network is more effective in addressing international terrorism. This may reduce dubious exercise of preemptive self-defense, which in turn may reduce unnecessary conflict over this issue.

\section{Conclusion}

Given the nature of the current international disputes, the exercise of allegedly preemptive self-defense will continue to rise. The concept of preemptive self-defense will also emerge in the context of terrorism prevention. The respectively controversial nature of the preemptive self-defense and international terrorism make the preemptive self-defense in the course of terrorism prevention ever more controversial and complex. Therefore, it is critical to come up with reliable jurisprudence applicable to this unique situation. The basic formula could still be found from the Caroline standard and the Article 51 of the U.N. Charter. However, it is also necessary to recognize the unique traits of the international terrorism and to take those traits into consideration in examining preemptive self-defense in terrorism context.

Even if the concept of preemptive self-defense is basically accepted in the context of terrorism prevention, it is critical that there is a mechanism in place to deter or punish an abuse of the right. It should be noted that the concept of self-defense, whether 
preemptive or present, is an exception to the general prohibition of use of force under international law and that most of the time terrorism prevention could be more properly dealt with in the criminal law enforcement aspect. It is critical for the international community to realize that the spirit of the U.N. Charter as codified in Articles 2(4) and 51 could be easily nullified in this regard.40

40 One commentator mentioned that "[a misguided]preemptive self-defense would provide legal justification for Pakistan to attack India, for Iran to attack Iraq, for Russia to attack Georgia, for Azerbaijan to attack India, for Iran to attack Iraq, for Russia to attack Georgia, for Azerbaijan to attack Armenia, for North Korea to attack South Korea, and so on.” See Mary Ellen O'Connell, supra note 6, at 19. 